\title{
ENHANCED HETEROLOGOUS EXPRESSION IN E.COLI
}

\author{
KATALIN NAGYa ${ }^{a}$ ZITA KOVÁCS ${ }^{b}$, PÁL SALAMON ${ }^{b}$,

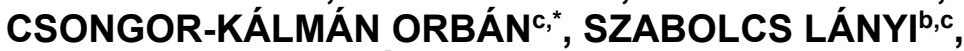 \\ BEÁTA ALBERT ${ }^{\mathrm{a}, \mathrm{c}}$
}

\begin{abstract}
Apoptotic regulation has been implicated in many human diseases, including cancer, autoimmune disease, inflammation and neuro degradation. Mapping up critical apoptosis regulators is a strategy for the development of new therapies [1, 2].

Present work highlights optimization of heterologous expression conditions for the X-linked inhibitor of apoptosis protein (XIAP). Genes of target protein containing pGEX-4T vector was transformed in chemically competent $E$. coli Rosetta $^{\mathrm{TM}}$ (DE3)pLysS cells. The recombinant construct contained a glutathione S-transferase (GST) fusion partner, which assured the purification of the protein by affinity chromatography. In the next step we examined the growth dynamics of the expression culture in M9 minimal medium, meanwhile we also determined the appropriate time of induction. Following this we carried out the optimization of expression, examining the expression's effectiveness under different conditions. On the basis of these fermentation experiments the target protein expression was the most prominent at $18^{\circ} \mathrm{C}$ with $0.2 \mathrm{mM}$ IPTG induction for 12 hours. During large scale fermentation experiments, we followed the optical density (OD), dry cell weight and substrate utilization. Finally, recombinant protein expression inhancement in the presence of $3 \%$ ethanol was successfully achieved in bioreactor. In this case the target protein was expressed in inclusion bodies, therefore solubilisation and refolding is necessary.
\end{abstract}

Keywords: XIAP, heterologous expression, optimization, bioreactor, ethanol

a University POLITEHNICA of Bucharest, Faculty of Applied Chemistry and Materials Science, Str. Gh. Polizu, Nr. 1-7, Sector 1, 011061 Bucuresti, Romania

b University of Pécs, Faculty of Sciences, Ifjúság útja 6., 7624 Pécs, Hungary

c SAPIENTIA Hungarian University of Transylvania, Faculty of Economics, Socio-Human Sciences and Engineering, Department of Bioengineering, 1 Libertatii Square, RO-530104, Miercurea Ciuc, Romania

*Corresponding author: orbancsongor@uni.sapientia.ro 
KATALIN NAGY, ZITA KOVÁCS, PÁL SALAMON, CSONGOR-KÁLMÁN ORBÁN, SZABOLCS LÁNYI, BEÁTA ALBERT

\section{INTRODUCTION}

Biologically active human proteins are useful for studying the biological functions of genes in different disease, for the development of therapeutic drugs and biomaterials in biotechnology industry [1].

In multicellular organism, apoptosis - genetically programmed cell death- is an ordinary and important process. Apoptotic regulation has been implicated in cancer. About 7 million people die from cancer-related cases per year, and it is estimated that there will be more than 16 million new cancer cases every year by 2020 [3].

The inhibitor of apoptosis proteins (IAPs) contains approximately 70 amino acid motifs termed baculovirus IAP repeat domains (BIR) [4]. Human X-linked inhibitor of apoptosis protein (XIAP), contains 3 BIR domains in the $\mathrm{N}$-terminal region, a RING domain and UBA domain. The BIR1 domain interacts with TAK1 (TGF $\beta$-activated kinase) and TAB1 (TAK1 binding protein 1) [5]. The BIR2 domain mediates interaction of XIAP's with active caspase-3 and -7 [6]. The BIR3 domain binds to procaspase- 9 [7]. Beside BIR domains, XIAP contains an UBA domain, which mediates association with mono- and polyubiquitin chains [8]. The RING domain (zinc finger domain) confers E3 ubiquitin ligase activity [9]. The IAP family member's cIAP1 and cIAP2 have an architecture similar to XIAP. As the most potent caspase inhibitors in IAP family, XIAP binds to and thus inhibits caspases in the initiation (caspase-9) and execution (caspase-3 and-7) phases of apoptosis. The inhibitory function of XIAP is antagonized by Smac-DIABLO (second mitochondria-derived activator of caspases-direct IAP binding protein with low pl).

According to literature, high levels of XIAP have been found in several cancer cell lines. The physiological amount of Smac-DIABLO released from the mitochondria may not be sufficient to overcome the inhibitory effect of XIAP on the caspases, thus preventing apoptosis [10]. Inactivation of overexpressed XIAP by Smac mimetic molecules may relieve caspase binding, thereby promoting apoptosis in malignant cells[11][12].

Nowadays, many therapeutic proteins and peptides are produced by biosynthesis. Insertion of the gene in the heterologous host is performed by recombinant techniques. In literature many reviews have covered the heterologous expression systems with great detail [13] [14]. In practice, planning an expression and carrying out it seems difficult. Many factors and circumstances need to be considered during expression planning. First of all, we need to examine ways to isolate gene of interests. Planning an expression system include the following factors: choosing the appropriate and well-functioning expression plasmid (vector), choosing the convenient organism for expression, troubleshooting the recombinant protein production, purification and structural analysis. E. coli expression system remain to be the preferred system for laboratory investigations and initial development in 
commercial activities because is a well-established host with short culturing time and easy genetic manipulation. Within E. coli expression, the T7 system is the most popular approach for producing proteins. In this system, an expression vector containing a gene of interest cloned downstream of the T7 promoter is introduced into a T7 expression host.

The GST fusion system can be characterized as a versatile expression system. Expression is under the control of the tac promoter and a repressor protein transcribed by $/$ ac $/ 9$ gene, thus maintaining tight control over expression of the insert. Promoter is the key component of an expression system because of its role in controlling the transcription initiation. An ideal promoter is strong enough to allow product accumulation up to $50 \%$ of the total cellular proteins, and is tightly regulated to prevent product toxicity. As a very strong hybrid promoter, tac promoter consists of the -35 region of the trp (tryptophan) promoter and the -10 region of the lac promoter. The GST fusion proteins can be purified from bacterial lysates by affinity chromatography using immobilized glutathione.

Enhancing recombinant protein expression level in most cases is limited. We found studies with the goal to develop food-grade expression systems by eliminating antibiotic selection markers [15]. These expression systems proved to be biosafe and also substantially increase final recombinant protein yields. Another possibility for improvement expression is secretion. For example, Shruti and coworkers developed a novel signal peptide sblggt (native signal of Bacillus licheniformis ER15 ggt gene) recognized and cleaved by signal peptidases of E. coli BL21 (DE3) cells which allowed high secretion to medium [16].

In our research we have used various molecular strategies to express XIAP in pGEX-4T expression system by optimizing various parameters such as, cultivation temperature, inducer concentrations, cell growth, and use of additives in culture medium. Gaurav and co-workers investigated ethanol, as an additive in culture medium [17]. Based on their results, ethanol proved to be efficient additive to increase protein expression in $E$. coli.

\section{RESULTS AND DISCUSSION}

\section{Determination of cell culture growth parameters}

The unlimited growth of a bacterial population has an exponential nature, with cells doubling after generation time. In a closed culture vessel, the exponential growth of the bacteria cannot continue indefinitely, as no fresh medium is added to the culture during the cultivation, the nutrient concentration is continuously decreasing and thus the number of cells over time can be divided into characteristic phases. Representing different stages of growth as a function of time gives the growth curve of bacterial populations. 
Heterologous expression is characterized by de novo fermentation, which can be divided into two phases. If protein production is intracellular, the amount of target protein is directly proportional to the amount of biomass, consequently first phase is biomass formation. Thereafter, induction of the cells results in the expression of the protein. For sensitive heterologous proteins, it is necessary to optimize expression conditions to achieve higher yields.

At this stage of our research the growth of the cell culture was examined in the interest of determine optimal cell density for induction. The cell growth media is chemically well-defined nutrient solution (M9 minimal medium), in which bacterial metabolism is different compared to a most commonly used (Luria-Bertani broth) medium.

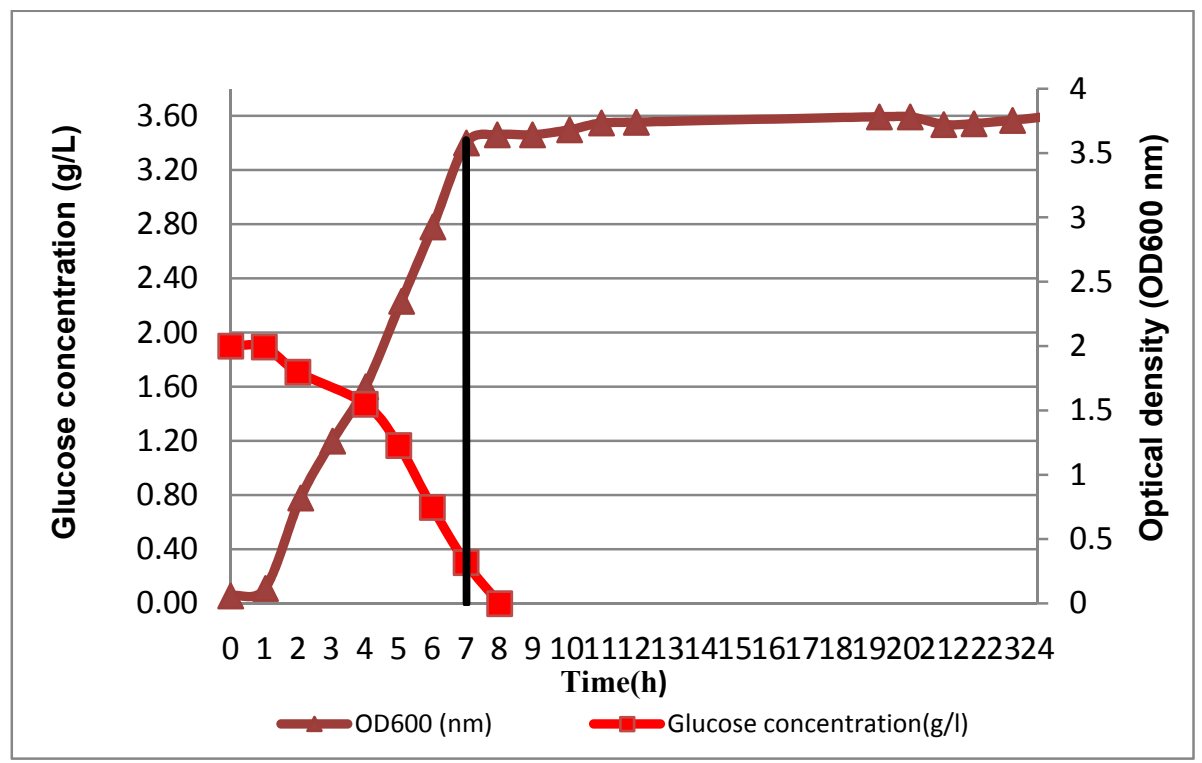

Figure 1. E. coli Rosetta ${ }^{\mathrm{TM}}(D E 3) p L y s S$ growth curve

According to our experiments, cell culture growth is characterized: 1 hour passed from an adaptive phase (lag phase) to an exponential phase that lasted for 7 hours, then the metabolism of the cells slowed down, their growth stopped and entered a stationary phase. The glucose concentration from the samples was determined by HPLC on CARBOSep COREGEL 87H3 column. If we examine the glucose concentration in the exponential phase we can declare that between the first and the seventh hour, the average glucose depletion rate is $0.278 \mathrm{~g} / \mathrm{h}$. 
Since glucose concentration reached $0.317 \mathrm{~g} / \mathrm{mL}$ at the $7^{\text {th }}$ hour, and then cells were transferred to the stationary phase, it can be assumed that this low glucose concentration results in reduced cellular metabolism.

The specific growth rate of cell culture was calculated using the optical density values, and the Monod model was used for the calculation $\left(0.304 \mathrm{~h}^{-1}\right)$. Conditions for selecting the induction time are as follows: primarily, the cell culture should be in an exponential phase, since the metabolism of the cells is set for self-replication and not for survival.

By examining the growth curve and the glucose depletion rate, we decided to induce the cell culture at $\mathrm{OD}_{600}=1.5$, because the broth contains plenty of glucose and is in the exponential phase of cell culture.

\section{Optimization of XIAP protein expression}

Results about shake flask expression in M9 minimal medium induced with different final concentrations of IPTG are summarized in this section. Samples taken every 3-3 hours in the interest of determine target protein concentration were investigated by SDS-PAGE analysis. These samples from whole cells were too small amount to pass through a purification phase. Our results are shown in the figures below.

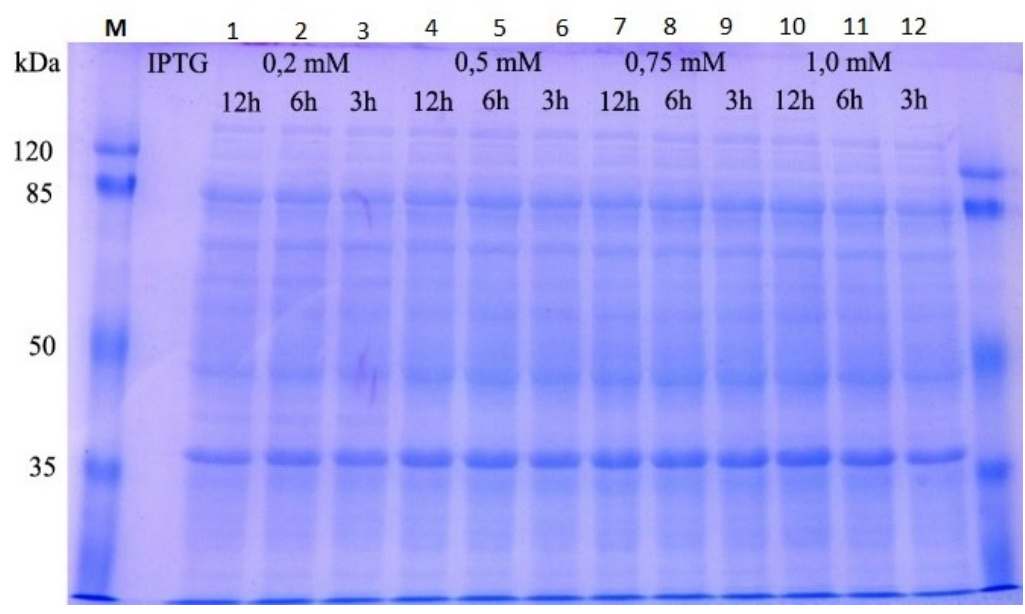

Figure 2. $10 \%$ SDS-PAGE gel analysis of expressed XIAP-GST at $37^{\circ} \mathrm{C}$.Protein samples were separated by $10 \%$ SDS-PAGE and stained with CBB. (M)-PageRuler ${ }^{\mathrm{TM}}$ Prestained NIR Protein Ladder, (molecular weight marker from Thermo Scientific ${ }^{\mathrm{TM}}$ ); (1)-0.2 mM IPTG induction-12h; (2)-0.2 mM IPTG induction-6h; (3)-0.2 mM IPTG induction-3h; (4)-0.5 mM IPTG induction-12h; (5)-0.5 mM IPTG induction-6h; (6)-0.5 mM IPTG induction-3h; (7)-0.75 mM IPTG induction-12h; (8)-0.75 mM IPTG induction-6h; (9)-0.75 mM IPTG induction-3h; (10)-1.0 mM IPTG induction-12h; (11)-1.0 mM IPTG induction-6h; (12)-1.0 mM IPTG induction-3h. 
Figures 2. and 3. shows expression level of XIAP at 18 and $37^{\circ} \mathrm{C}$, varying IPTG concentration and incubation time. XIAP is a $53 \mathrm{kDa}$ (http://media.cellsignal.com/pdf/2042.pdf) sized protein and with GST it has $78 \mathrm{kDa}$. It is observed that proteins were produced only at $18^{\circ} \mathrm{C}$ for 12 hours. We can observe differences at concentration of inducer. Unfortunately, the target proteins were expressed in inclusion bodies. In conclusion we declare no protein expression were observed at $37^{\circ} \mathrm{C}$.

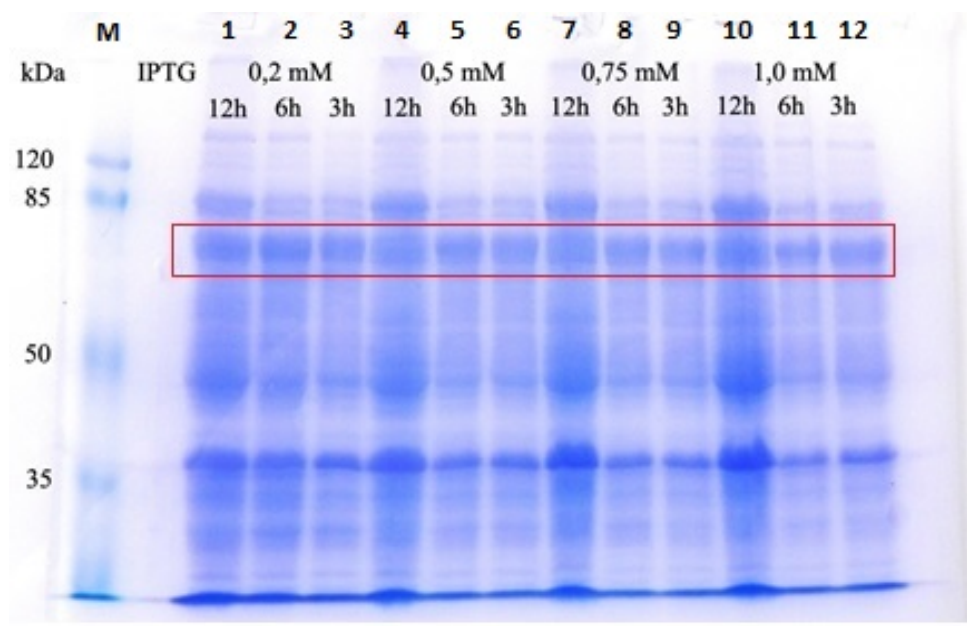

Figure 3. 10\% SDS-PAGE gel analysis of expressed XIAP-GST at $18{ }^{\circ} \mathrm{C}$.Protein samples were separated by $10 \%$ SDS-PAGE and stained with CBB. (M)-PageRuler ${ }^{\mathrm{TM}}$ Prestained NIR Protein Ladder, (molecular weight marker from Thermo Scientific ${ }^{\text {TM}}$ ); (1)- 0.2 mM IPTG induction-12h (2)-0.2 mM IPTG induction- 6h; (3)-0.2 mM IPTG induction- 3h; (4)- $0.5 \mathrm{mM}$ IPTG induction-12h; (5)- 0.5 mM IPTG induction-6h; (6)-0.5 mM IPTG induction-3h; (7)-0.75 mM IPTG induction-12h; (8)-0.75 mM IPTG induction-6h; (9)-0.75 mM IPTG induction-3h; (10)-1.0 mM IPTG induction-12h; (11)-1.0 mM IPTG induction-6h; (12)$1.0 \mathrm{mM}$ IPTG induction-3h.

Considering the cell growth over expression (Table 1), a slight difference is observed in optical density increase, as the concentration of IPTG increases, the optical density decreases.

Table 1. Changes in optical density of cell culture during XIAP expression at 18 and $37^{\circ} \mathrm{C}$

\begin{tabular}{|c|c|c|c|c|}
\hline $\mathrm{XIAP} / 18^{\circ} \mathrm{C}$ & $0,2 \mathrm{mM}$ & $0,5 \mathrm{mM}$ & $0,75 \mathrm{mM}$ & $1,0 \mathrm{mM}$ \\
\hline $3 \mathrm{~h}$ & 0,68 & 0,768 & 0,712 & 0,712 \\
\hline $12 \mathrm{~h}$ & 2,736 & 2,656 & 2,544 & 2,488 \\
\hline $\mathrm{XIAP} / 37^{\circ} \mathrm{C}$ & $0,2 \mathrm{mM}$ & $0,5 \mathrm{mM}$ & $0,75 \mathrm{mM}$ & $1,0 \mathrm{mM}$ \\
\hline $3 \mathrm{~h}$ & 0,712 & 0,704 & 0,792 & 0,76 \\
\hline $12 \mathrm{~h}$ & 1,664 & 1,264 & 1,152 & 1,112 \\
\hline
\end{tabular}


As a result of over-expression, the induction causes the protein production to start and the proteins to poison the cells.

Finally, it can be concluded that the protein expression in bioreactor should be performed at $18{ }^{\circ} \mathrm{C}$ for 12 hours with $0.2 \mathrm{mM}$ IPTG inducer concentration.

\section{Enhanced expression of human recombinant XIAP protein in bioreactor}

To ensure high-yield production of target protein, a bioreactor system was used for cultivation of transformed expression strains under controlled process parameters offering the possibility to obtain high biomass levels, and consequently, high protein production rates.

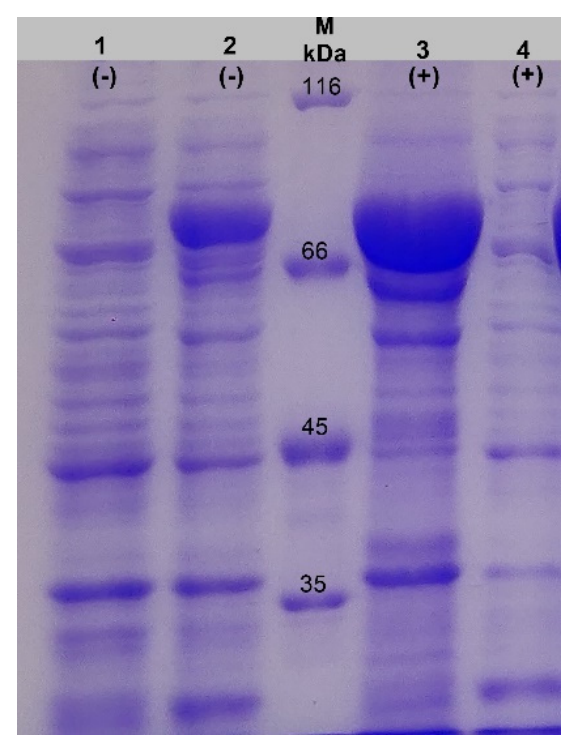

Figure 4. $10 \%$ SDS-PAGE gel analysis of increased XIAP production. Protein samples were separated by $10 \%$ SDS-PAGE and stained with CBB.(1)-supernatant after cell disruption in absence of ethanol (-); (2)-pellet after cell disruption in absence of ethanol I (-); (M)-peqGold Prestained protein marker I. (molecular weight marker from VWR); (3)-pellet after cell disruption in presence of ethanol $(+)$; (4)-supernatant after cell disruption in presence of ethanol (+)

To enhance the expression, and increase the production of recombinant protein, the feed broth contained 3\% ethyl alcohol. The amount of recombinant protein expression was increased 8.55 fold, but also in this case the proteins were expressed in inclusion bodies. Expression of recombinant proteins in $E$. coli under ethanol treatment is a unique technique. Ethanol can affect the cellular environment including membrane fluidity, membrane transport, membrane lipid composition and also the assembly of membrane proteins. 
DNA replication is a membrane associated phenomena therefore it is affected by ethanol concentration. Among future plans we'll design appropriate solubilization and refolding of XIAP from inclusion body.

\section{CONCLUSIONS}

In the current phase of our research we proved a successful expression procedure for biosynthesis of XIAP. Firstly, expression conditions were optimized successful, and also investigation of expression in bioreactor was effective. The best expression level was achieved at the following parameters: $0.2 \mathrm{mM} \mathrm{IPTG}, 18^{\circ} \mathrm{C}$, and 12 hours.

The $3 \%$ ethyl alcohol used to increase the production of recombinant protein was able to increase protein levels, but unfortunately in inclusion bodies, therefore solubilisation and refolding are necessary steps towards protein purification.

\section{EXPERIMENTAL SECTION}

All chemicals, bacterial growth media used for our experiments were purchased from commercial sources (Sigma Aldrich, Merck, BioLabs and Thermo scientific). Bacterial strains were also obtained from commerce (AddGene, BioZyme).

\section{Investigation of cell culture growth parameters}

Our goal was to determine the optimal point for induction on the exponential phase of cell growth, as a function of substrate concentrations. We measured the optical density of cell culture and concentration change of glucose during fermentation. To determine the growth curve, we prepared the inoculum as a first step. $100 \mu \mathrm{l}$ of the transformed stock of $E$. coli Rosetta $^{\mathrm{TM}}$ (DE3)pLysS was inoculated into $10 \mathrm{ml}$ of Ampicillin-containing LB medium in $50 \mathrm{ml}$ centrifuge tubes and incubated for 4 hours at $37^{\circ} \mathrm{C}$. In a second step, the pre-culture was inoculated into a $500 \mathrm{ml}$ Erlenmeyer flask containing $200 \mathrm{ml} \mathrm{M9}$ minimal medium and then incubated at $37^{\circ} \mathrm{C}, 250 \mathrm{rpm}$. $1 \mathrm{ml}$ of sample was taken per hour and the optical density (OD) was measured at $600 \mathrm{~nm} .1 \mathrm{ml}$ of sample was centrifuged at 10,000 rpm for 10 minutes and the supernatant stored in a refrigerator for subsequent glucose measurement. The growth of the bacterium was monitored in triple repetitions for 18 hours. Components of M9 minimal medium are the followings: $\mathrm{Na}_{2} \mathrm{HPO}_{4}(3,548 \mathrm{~g} / \mathrm{L}), \mathrm{KH}_{2} \mathrm{PO}_{4}(3,401 \mathrm{~g} / \mathrm{L}), \mathrm{NaCl}(0.5 \mathrm{~g} / \mathrm{L})$, $\left(\mathrm{NH}_{4}\right)_{2} \mathrm{SO}_{4}(2 \mathrm{~g} / \mathrm{L}), \mathrm{C}_{6} \mathrm{H}_{12} \mathrm{O}_{6}(2 \mathrm{~g} / \mathrm{L}), \mathrm{MgSO}_{4}(2 \mathrm{mM}), \mathrm{CaCl}_{2}(0,02 \mathrm{mM})$, Trace elements(1x), Antibiotic (Ampicillin, $100 \mu \mathrm{g} / \mathrm{mL}$ ). 


\section{Optimization of XIAP heterologous expression}

Optimization of heterologous expression of XIAP was investigated in E. coli Rosetta ${ }^{\mathrm{TM}}$ (DE3)pLysS cell line at different temperatures, with 0.2-1 mM IPTG inducer concentrations for 12 hours. The expression of XIAP protein was investigated using the following methods at $37^{\circ} \mathrm{C}$. At first, we prepared the inoculum: E. coli Rosetta ${ }^{\mathrm{TM}}$ (DE3)pLysS with pGEX-4T-XIAP transformed cells were inoculated into $8 \times 10 \mathrm{~mL}$ LB-Ampicillin broth and incubated in shaking incubator $(250 \mathrm{rpm})$ at $37^{\circ} \mathrm{C}$ for 4 hours. Thereafter, $100 \mu \mathrm{l}$ of the preculture in LB broth was transferred to 8 sterile centrifuge tubes containing $10-10 \mathrm{ml}$ of M9 minimal medium and incubated in shaking incubator (250 rpm) at $37^{\circ} \mathrm{C}$.

The cell density was measured hourly. When it reached $\mathrm{OD}_{600}=1.5$, the protein expression was induced with isopropyl-thiogalactopyranoside (IPTG) at various concentration $(0.2 \mathrm{mM}, 0.5 \mathrm{mM}, 0.75 \mathrm{mM}, 1 \mathrm{mM})$. After 3, 6 and 12 hours, $1-1 \mathrm{ml}$ of sample was taken, centrifuged at 10,000 rpm, 10 min, the supernatant was discarded and lysis buffer $(50 \mathrm{mM}$ Tris- $\mathrm{HCl}(\mathrm{pH}$ 7,5), $250 \mathrm{mM} \mathrm{NaCl}, 2 \mathrm{mM}$ DTT, $1 \mathrm{mM}$ PMSF, protease inhibitor cocktail) was added to the pellet-containing tubes, diluted to $\mathrm{OD}_{600}=1.5$, wherewith was resuspended. $2 X$ Laemmli Sample buffer was added to the tubes and placed in incubator with $98^{\circ} \mathrm{C}$ for 10 minutes. After the incubation time, the cells were sonicated, then centrifuged and assayed by SDS-PAGE gel electrophoresis. Following this process, next experiment was performed at $18{ }^{\circ} \mathrm{C}$ using the same procedure.

\section{Expression of human recombinant XIAP protein in bioreactor}

Recombinant protein production was carried out in a $1 \mathrm{~L}$ capacity Sartorius Biostat $₫ A$ Plus Bioreactor, using BioPAT $®$ MFCS/DA Supervisory Control and Data Acquisition (SCADA) Software. The reactor was firstly loaded with $0.7 \mathrm{~L}$ basic M9 minimal medium. The system was autoclaved for 20 minutes at $120{ }^{\circ} \mathrm{C}$, in order to ensure sterility. After sterilization, the reactor was connected to aeration, acid and base solutions, temperature control system and control unit. After the reactor has cooled down $\left(40^{\circ} \mathrm{C}\right)$, thermally unstable compounds were added through a sterile filter $(0.25 \mu \mathrm{m})$. In order to homogenize the system, mixing, temperature, and $\mathrm{pH}$ control were launched: $400 \mathrm{RPM}, 37^{\circ} \mathrm{C}, \mathrm{pH}$ 6.9. After the stabilization of the reactor, the media was inoculated under sterile conditions with $15 \mathrm{~mL}$ inoculum. The culture at this stage was grown at $37^{\circ} \mathrm{C}$, with a dissolved oxygen level above $40 \%$, and $\mathrm{pH} 6.9$. When the cell density reached $\mathrm{OD}_{600}=8$, the temperature was set to $18{ }^{\circ} \mathrm{C}$ and the protein expression was induced with isopropylthiogalactopyranoside (IPTG) $(0.2 \mathrm{mM}$ final concentration). Protein expression was carried out at $18^{\circ} \mathrm{C}$, O.N. (12 hours).

In order to harvest the cells, $0.7 \mathrm{~L}$ culture was centrifuged $(12,000 \mathrm{xg}$ for $10 \mathrm{~min}$ at $4{ }^{\circ} \mathrm{C}$ ), and the cell pellets were stored at $-80^{\circ} \mathrm{C}$ until further processing (Thermo Scientific FORM 88000 series). 
KATALIN NAGY, ZITA KOVÁCS, PÁL SALAMON, CSONGOR-KÁLMÁN ORBÁN, SZABOLCS LÁNYI, BEÁTA ALBERT

Cell lysis was performed as follows: 1 gram of cells were resuspended in $5 \mathrm{~mL}$ of lysis buffer ( $50 \mathrm{mM}$ Tris- $\mathrm{HCl}$ (pH 8), $150 \mathrm{mM} \mathrm{NaCl}, 2 \mathrm{mM} \mathrm{DTT}, 1 \mathrm{mM} \mathrm{PMSF}$, $1 \mathrm{x}$ protease inhibitor cocktail). Cell disruption was performed with a Microfluidizer LM10, in order to increase the efficiency, the micro-flight compression was performed twice. The resulting cell extract was centrifuged at $4{ }^{\circ} \mathrm{C}, 60,000 \mathrm{xg}$, for 60 minutes in order to separate the solubilized proteins from cellular debris.

For quantification of expressed XIAP recombinant protein we used GelQuant, NET software provided by biochemlabsolutions.com.

\section{ACKNOWLEDGMENTS}

The research work was supported by the project: Controlul funcţiilor celulelor dendritice cu semnale anti-inflamatoare şi de moarte celulară- DCFANS (Code Project: PN-II-PT-PCCA-2013-4; Financing: Cerere de finanţare Proiecte Colaborative de Cercetare Aplicativă).

\section{REFERENCES}

1. S. Nagata, Annu. Rev. Immunol., 2018, 36, 489-517.

2. A.C. West, B.P. Martin, D.A. Andrews, S.J. Hogg, A. Banerjee, G. Grigoriadis, R. W. Johnstone, and J. Shortt, Oncogenesis, 2016, 5, 1-6.

3. R. Hammami and I. Fliss, Drug Discov. Today, 2010,15, 540-546.

4. K. Welsh, D. Finlay, R.J. Ardecky, S. Reddy, M. González-lo, Y. Su, P. Teriete, P.D. Mace, S.J. Riedl, K. Vuori, J.C. Reed, and N.D.P. Cosford, Bioorg. \& Med. Chem lett., 2011, 21, 4332-4336.

5. R. Hofer-warbinek, J.A. Schmid, C. Stehlik, B.R. Binder, J. Lipp, and R. De Martin, JBC, 2000, 275, 22064-22068.

6. Y. Suzuki, Y. Nakabayashi, K. Nakata, J.C. Reed, and R. Takahashi, JBC, 2001, 276, 27058-27063.

7. E.N. Shiozaki, J. Chai, D.J. Rigotti, S.J. Riedl, P. Li, S.M. Srinivasula, E.S. Alnemri, R. Fairman, and Y. Shi, Mol. Cell, 2003, 11, 519-527.

8. M. Gyrd-Hansen, M. Darding, M. Miasari, M.M. Santoro, L. Zender, W. Xue, T. Tenev, P.C.A. Fonseca, M. Zvelebil, J.M. Bujnicki, S. Lowe, J. Silke, and P. Meier, Nat Cell Biol., 2008, 10, 1309-1317.

9. D.L. Vaux, J. Silke, T. Walter, and E. Hall, Nat. Rev. Mol. Cell Biol., 2005, 6, 287-297.

10. E. Mastrangelo, F. Cossu, M. Milani, G. Sorrentino, D. Lecis, D. Delia, L. Manzoni, C. Drago, P. Seneci, C. Scolastico, V. Rizzo, and M. Bolognesi, J. Mol. Biol., 2008, 384, 673-689.

11. S. Fulda, Clin. Cancer Res., 2015, 21, 5030-5037.

12. S.W. Haiying Sun, Zaneta Nikolovska-Coleska, Chao-Yie Yang, Dongguang Qian, Jianfeng Lu, Su Qiu, Longchuan Bai, Yuefeng Peng, Qian Cai, Acc. Chem. Res., 2009, 41, 1264-1277.

13. R. Chen, Biotechnol. Adv., 2012, 30, 1102-1107.

14. G.L. Rosano and E. A. Ceccarelli, Front. Microbiol, 2014, 5, 1-17.

15. P.H. Oliveira and J. Mairhofer, Trends Biotechnol., 2013, 31, 539-547.

16. S. Bindal, V.K. Dagar, M. Saini, Y. P. Khasa, and R. Gupta, Enzyme Microb. Technol., 2018, 116, 23-32.

17. J. Kaur, A. Kumar, and J. Kaur, Int. J. Biol. Macromol., 2018, 106, 803-822. 